\title{
Globalization: the mechanicalization of the world
}

\begin{abstract}
In this article, I put forth the argument that globalization represents a Durkheimian mechanicalization of the world via the Protestant Ethic and the spirit of capitalism under American hegemony, and contemporarily the earth itself and Islamic Fundamentalism are the last remaining counter-hegemonic forces to this process, which threatens all life on earth.
\end{abstract}

Keywords: Ideological domination, capitalism, underclass, globalization, blacks, theory, globalization as culture, culture of globalization
Volume 2 Issue 6 - 2018

\author{
Paul C Mocombe \\ Department of Sociology \& Philosophy, West Virginia State \\ University, USA
}

Correspondence: Paul C Mocombe, Department of Sociology \& Philosophy, West Virginia State University, The Mocombeian Foundation Inc, USA, Email pmocombe@mocombeian.com

Received: October 19,2018 | Published: December 26, 2018

\section{Introduction}

Globalization represents a Durkheimian mechanicalization of the world via the Protestant Ethic and the spirit of capitalism under American (neoliberal) hegemony, and contemporarily the earth itself and Islamic Fundamentalism are the last remaining counterhegemonic forces to this process, which threatens all life on earth.

Sociological theory regarding the contemporary (1970s to the present) phenomenon of globalization focuses either on convergence or hybridization. The former, convergence, highlights the everincreasing homogenization of cultures and societies around the globe via socioeconomic rational forces. From this perspective globalization is tantamount to Westernization or Americanization of other cultures and societies via neoliberal economic, market, subjugation. The latter, hybridization, emphasizes heterogeneity, the mixture of cultural forms out of the integration of society via globalizing processes stemming from improvements in information technology, communications, mass media, etc. In this latter form, cultures and societies are not homogenized, but are cultural forms that are syncretized with liberal democratic Western capitalist rational organization. In this work, I want to propose that in globalization under American hegemony both positions are purporting the same process, convergence, and that the only alternative to this thesis of convergence is Samuel P. Huntington's (1996) differential hypothesis, which purports a clash of civilization as a result of the intransigence positions of eight cultural frameworks, Sinic, Japan, Hindu, Islamic, Orthodox, Western Europe, North America, and Africa, which dominate the globe. In refutation to Huntington's thesis, however, I propose the hypothesis that, contemporarily, there are really only two opposing counter-hegemonic forces to the convergence towards Westernization or Americanization, the earth itself and Islamic Fundamentalist movements. The earth is counter-hegemonic to globalizing processes because of the ecological devastations, i.e., global warming, soil erosion, resource depletion, etc., associated with capital accumulation and capitalist relations of production, which antagonistically pins the material resource framework, the earth, against the logic of economic growth encapsulated in the neoliberal Protestant discourse of the global social structure of inequality under American hegemony. Islamic Fundamentalism's anti-American traditionalism makes it a viable counter-hegemonic force to globalization under American hegemony. Hybridization, on the contrary, is not an alternative to the convergence thesis, but complements it because the hypothesis here is that the purposive-rationality of the hybrid cultures when they encounter globalizing processes under American Hegemony is for equality of opportunity, recognition, and distribution, not to overthrow or offer a counter hegemonic alternative systemicity to a process, capital accumulation, which threatens all life on earth. In fact, hybridization for American capital following the civil rights movement of the 1960s would become the mechanism for social integration of ethnic other communities in globalization under American hegemony.

\section{Background of the problem}

"Culture of globalization" and the "globalization as culture" metaphors represent two sociological approaches to understanding the contemporary postmodern phenomenon we call globalization (1970s-2000s). These two sociopolitical understandings regarding the origins and nature of globalization, as Kevin Archer ${ }^{1}$ points out, have "set off a vigorous and at times rancorous debate within the social sciences" (2007, pg. 2). On one side of the debate you have theorists who emphasize the "culture of globalization" and argue the idea that "the constitutive role of culture is critical for grasping the continued hegemony of capitalism in the form of globalization... Culture, they assert is increasingly being co-opted and deployed as a new accumulation strategy to broaden and deepen the frontiers of capitalism and to displace its inherent crisis tendencies". ${ }^{1}$ In a word, in the continual hegemonic quest of capitalism to homogenize the conditions of the world to serve capital, globalization, in the eyes of "culture of globalization" theorists, represents a stage of capitalism's development highlighted by the commodification of culture as a means for accumulating profits from the purchasing and consuming power of a transnational class of administrative bourgeoisies and professional cosmopolitan elites in core, semi-periphery, and periphery nationstates who subscribe to the social integrative norms of liberal bourgeois Protestantism (hard work, economic gain, political and economical liberalism, consumption, etc.).

In other words, the material and symbolic cultural elements of the cultures of the world are commodified by the upper class of owners and high-level executives of core countries to make a profit or produce surplus-value by fulfilling the consumption tastes of the financiers, administrative bourgeoisies, professional classes, and cosmopolitan elites of nation-states throughout the world who control their masses 
as a surplus labor force for global capital. Globalization, therefore, is simultaneously the outsourcing of industrial work to other nations, and the integration of the cultural realm into the commodity chains of the capitalist elites, the upper class of owners and high-level executives, who interpellate and homogenize, through the media and other "ideological state apparatuses," the behavior and tastes of global social actors as consumers and workers in order to generate profit in postindustrial economies.

This "culture-of-globalization" understanding of globalization or the postmodern condition in late capitalist development is a well supported position, which highlights, in the twenty-first century, the continued hegemony of capitalism in the form of globalization. ${ }^{2-4}$ This line of thinking, in which theorists point to the underlining drive of globalization as the continuing historical push to socially, economically, and politically (under) develop the rest of the world along the lines, or as a simulacrum, of Western American and European Societies to facilitate capital accumulation, began with European colonialism, continued through the "development project" of the Cold-war era, and now is embodied in the globalization process. This historical process is highlighted in modernization, development, dependent development, world-systems theories, and contemporarily it is a trend outlined in the theoretical works of postmodern theorists such as David Harvey ${ }^{5}$ and Fredric Jameson ${ }^{4}$ who view globalization as postmodern or the cultural logic of capitalist development in core or developed countries

"Globalization-as-culture" theorists out rightly reject this socioeconomic position or interpretation underlying the emergence and processes of globalization. They believe "that globalization is marked by the hollowing out of national cultural spaces either consequent upon the retrenchment of the nation state or because culture continues to be a relatively autonomous sphere". ${ }^{1}$ That is, "for the "globalization-as-culture" group...culture is not that easily enjoined due to its inherent counter-hegemonic properties vis-à-vis neo-liberal globalization. Rather, for this group..., contemporary globalization is not merely economic, but a system of multiple cultural articulations which are shaped by disjunctive space-time coordinates. In other words, globalization is as much if not more the product of inexorable and accelerated migratory cultural flows and electronic mass mediations beyond the space-time envelopes of the nation-state system and the successive socio-spatial fixes of global capitalism". In fact, culture, in many instances, serves as a counter-hegemonic movement to (neo) liberal capitalism as a governing "rational" system. This line of thinking is best exemplified in the works of, ${ }^{6,7}$ Helle ${ }^{8,9}$ among many others. For these theorists cultural exchanges are never one-dimensional, and hybridization of culture in many instances serves as a counter-hegemonic force to the homogenization processes of global capital. That is, as postcolonial hybrids in their encounter with their former colonizers dialectically convict the former colonial powers of not identifying with the lexicons of signification of their enlightenment ethos, the hybrid identity is counter-hegemonic as they seek equality of opportunity, recognition, and distribution with their white counterparts as an ethnic other. ${ }^{10,11}$

\section{Theory}

Theoretically, this debate between the advocates of the "globalization-as-culture" and the "culture-of-globalization" hypotheses is a fruitless debate grounded in a false ontological and epistemological understanding of the origins and nature of the (neo) liberal capitalist system that gives rise to the processes of globalization under American hegemony. ${ }^{12-15}$ Both groups ontologically and epistemologically assume that the origins of capitalism and its discursive practice is grounded in the dialectic of reason and rationality, thus drawing on the liberal distinction between capitalism as a public and neutral system of rationality that stands apart from the understanding of it as a private sphere or life world cultural form grounded in the ontology of the Protestant ethic and the spirit of capitalism as argued by Max Weber. ${ }^{16}$ The latter ontological position, if assumed by both schools, is a point of convergence that resolves their opposition, and gives a better understanding of the origins and nature of the processes of globalization and counter movements to what are in fact metaphysical cultural forces. ${ }^{17-20}$

Essentially, ${ }^{21}$ both schools of thought are putting forth the same convergence argument, the culture of globalization position from a Marxian systems integration perspective and the globalization as culture position from a Weberian social integration perspective. ${ }^{22}$ For the culture of globalization position cultural practices are homogenized to be integrated within the rational rules or systemicity of capitalist relations of production and consumption at the worldsystem level so as to generate surplus-value from the consumption of cultural products as commodities in core nations, industrial production in semi-periphery nations, and agricultural production in periphery nations. ${ }^{23-25}$

The globalization as cultural group suggests that in the process of acculturating social actors to the organization of work within the capitalist world-system, homogenization does not take place. Instead, in the process of integration within the world-system, ${ }^{26-30}$ cultural groups intersubjectivity defer meaning in ego-centered communicative discourse to hybridize the lexicons of significations coming out the globalization process thereby maintaining their cultural forms not in a commodified form but as a class-for-itself seeking to partake in the global community, via the retrenchment of the nation-state, as hybrid social actors governed by the liberal rational logic of the marketplace. ${ }^{30-34}$

The two positions are not mutually exclusive, however, and when synthesized highlight the same position, globalization, under American hegemony, contemporarily represents the homogenization of social discourse and action via hybridization. The latter, ${ }^{35}$ hybridization, as the mechanism of social integration in globalization under American hegemony, ${ }^{36}$ is the by-product of the black American civil rights movement of the 1960s coupled with the outsourcing of American industrial work to the rest of the world beginning in the 1970s. ${ }^{37,38}$

Following the Protestant Reformation and the rise of Protestants to positions of power within the Westphalian nation-state system all social actors were interpellated and socialized via Protestant churches to be obedient workers so as to obtain economic gain via the labor market. ${ }^{39} \mathrm{Be}$ that as it may, the church and the labor market (via education) became the defining institutions for socializing social actors as both Protestant agents and agents of and for capital. ${ }^{40}$ That is individuals, Protestant agents, with a work ethic that would allow them to pursue economic gain via their labor in a market as either agents for capital, laborer, or agents of capital, administrative bourgeoisie. The relationship, therefore, between the Protestant ethic and the capitalization of labor or the constitution of the labor market are not mutually exclusive. ${ }^{41}$ Instead they were and are necessary components for constituting a capitalist society under the metaphysical discourse of Protestantism. The Protestant Ethic and God, in a word, legitimated 
the organization of social actors as laborers, and the labor market was constituted to ensure that workers were rewarded accordingly to ensure that the discursive practices of the labor market were in line with the metaphysical discourse of the Protestant ethic. ${ }^{42}$

What the two sociological approaches to understanding globalization have done is to separate the dialectic and theorize their respective positions from opposite sides of the dialectic, the culture of globalization scholars from the side of labor organization (forces of production) and practices and the globalization as culture people from the side of social integration (social relations of production). The "culture of globalization" scholars identify the economic practices by which Protestant agents organized and organize social practices the world over to socialize individuals to become "agents of and for capital" for the purpose of generating surplus value or economic gain for capital. ${ }^{43-45}$ In a word, the organization of work and its relation to the desires of capital is the dominating factor in understanding the processes of globalization for the culture of globalization group. Given the mutual constitution of the Protestant ethic and the spirit of capitalism this latter position is not inaccurate as the labor market also serves to integrate the social actor as not only an agent of capital but also a Protestant agent, i.e., a worker who gains, status, upward economic mobility, etc. by being obedient and working hard. ${ }^{46}$

For the globalization as culture scholars the emphasis is on understanding how national cultures avoid being both an agent of capital and a Protestant agent to successfully carve out a national space within the globalizing process. This position is not an alternative to the culture of globalization group, but is actually saying the same thing. ${ }^{47}$ That is, in globalization under American hegemony the attempt of capital, the upper-class of owners and high-level executives operating predominantly out of the US, is to have national cultures carve out national spaces, nation-states, within a globa ${ }^{48}$ marketplace wherein every group can have a comparative advantage disseminating their natural and cultural resources so as to accumulate economic gain for themselves and national and global capital. So through the commodification of natural and cultural resources and cultural identities (their comparative advantage) for sale and consumption on the labor market global elites hybridize and universalize national discourse and discursive practices. . $^{49,50}$

Hybridized national cultures in this process are not counterhegemonic they are converging to meet the desires of global capital operating in postindustrial economies with emphasis on servicing the financial wealth of a transnational (phenotypically) multicultural capitalist class. There are only two instances in which national cultures in the globalizing process can become counter-hegemonic. Their discourse and discursive practices must stand in diametrical opposition to the two sides of the Protestant ethic and the spirit of capitalism. That is, their discourse and discursive practices must either attack the Protestant ethos of the dialectic, or the capitalist labor market it constitutes. For example, communism attacked the latter, i.e., the organization of the labor market and Islamic Fundamentalism with its emphasis on charity and Islamization attacks both the labor market and the Protestant ethos. Just the same, the earth with its global response to the degradation associated with industrial pollution, mismanagement of space, etc., threatens the labor market of capital, which is tantamount to the organization of society in contemporary times. Hence, just as communist Russia was a threat to capitalist societies in the twentieth century, communist Cuba, contemporarily, continues to serve as a failed counter-hegemonic national culture to capitalist processes or a more perfect modernity. Islamic fundamentalist societies and the earth itself also serve as counter-hegemonic national cultures. These are the only remaining counter-hegemonic forces against the universalizing processes of global capital. All others are hybrid liberal bourgeois Protestant nations interpellated and socialized by global capital via the church or the organization of work, i.e., the labor market and education, seeking equality of opportunity, recognition, and distribution in the global capitalist world-system's organization of labor and consumption patterns. Just the same, anti-globalization protest movements are not counter-hegemonic to globalizing processes. Their intent, just like the ethnic others in control of the ideological apparatuses of their nation-states, is simply for equality of opportunity, recognition, and distribution or a more perfect modernity within the systemicity of globalization or the global capitalist social structure under American hegemony. ${ }^{51}$ Hence, anti-globalization forces are not seeking to overthrow globalizing forces with their protests they are simply convicting them for their contradictory practices. Their fragmented protests are subsequently clamped down upon by the ideological apparatuses of global capital not because they offer a counterhegemonic discourse to globalization, but because their antics by which they seek the more perfect modernity undermines the control necessary for capital accumulation. In fact, in many instances, antiglobalization protests are reconceptualized by global capital as the sign of a healthy modern liberal bourgeois democratic society. ${ }^{52}$

It is this incessant claim for equality of opportunity, recognition, and distribution of the successful socialized hybrid liberal bourgeois Protestant agent of capital the "globalization as culture" scholars identify as being counter-hegemonic. ${ }^{53}$ This counter-hegemony highlighted by the "globalization as culture" camp is grounded in the fact that the hybrid liberal bourgeois Protestant is allowed to, and seeks to, compete in the global capitalist marketplace as a hybrid elite or Protestant agent and agent of and for capital against the gaze of their former colonial masters. ${ }^{54,55}$ This agential moment of hybrid others to participate in the global organization of labor is not counterhegemonic as the purposive-rationale of these hybrid agents is economic gain for themselves as an ethnic other at the expense of their poor but contemporarily represents the means by which Protestant agents operating out of the US attempt to universalize their purposiverationale among the others of the world so as to generate economic gain/surplus value or what amounts to the same thing reproduce the Protestant capitalist social system globally. ${ }^{56}$

Under American hegemony, capital, given their experience with the black American hybrid, has come to realize that the antagonizing hybrid seeking equality of opportunity, recognition, and distribution is a new market for capital accumulation and not a counterhegemonic force to the systemicity of the Protestant Ethic and the spirit of capitalism. ${ }^{57}$ Hence hybridization represents the integrative social mechanism for American capital, which is seeking to control global social ideas and actions within the liberal bourgeois Protestant discourse and discursive practices of the American-state post the civil rights movement and civil rights legislation. ${ }^{58,59}$

\section{Globalization and hybridization}

Globalization represents the discursive practice, "spirit of capitalism," of American agents of the Protestant Ethic seeking to interpellate and homogenize, through outsourcing, mass mediaization, and consumption patterns, "other" human behaviors, cultures, around 
the globe within the logic of their metaphysical discourse, "The Protestant Ethic and the spirit of capitalism," so as to accumulate profit, via agricultural, industrial, and post-industrial/consumerist production, for the predestined from the damned. ${ }^{60}$ That is, via globalization social actors around the globe are socialized, through state ideological apparatuses such as education and neoliberal market forces, funded by the IMF via the US nation-state, to become agents of the Protestant ethic so as to fulfill their labor and consumptive roles in the organization of work required by their nation-state in the global capitalist world-system under American hegemony. Integration via the retrenchment of the nation state under American global hegemony subsequently leads to economic gain and status for a few predestined, administrative bourgeoisie, or transnational capitalist class, that inturn become cultural consumers, given the mediaization of society, of bourgeois goods and services from postindustrial societies like America while the masses are taught (via the church or school) the Protestant work ethic to labor in agricultural, industrial, or tertiary tourist or financial industries. ${ }^{61}$ Hence, proper socialization of the other in the contemporary capitalist American dominated world-system is tantamount to hybridization, i.e., the socialization of the other as a liberal bourgeois Protestant other seeking equality of opportunity, recognition, and distribution with their white counterparts within the neoliberal framework of the global capitalist nation-state worldsystem under American hegemony. This process of integration via hybridization is the legacy or by-product of the black American civil rights movement, led by a liberal hybrid embourgeoised middle class, on global American capital. ${ }^{62}$

Civil rights legislation beginning with the 1954 Brown V. Board of Education of Topeka, Kansas and ending with the Civil Rights Act of 1964 undermined state-sanctioned segregation in all aspects of American life. Brown ended school segregation, and the act banned discrimination in places of public accommodation, including restaurants, hotels, gas stations, among many others. The Civil Rights Act of 1964 also banned discrimination by employers and labor unions on the basis of race, color, religion, national origin, and sex in regard to hiring, promoting, dismissing, or making job referrals. The purposive-rationality of liberal bourgeois black hybrid professionals, lawyers in particular, were largely responsible for these turn of events as they sought to partake in the fabric of American society by convicting the society of not identifying with its values as outlined in the constitution. These provisions would have particular importance for the process of outsourcing that American capital would undertake in the 1970s as they and the liberal black bourgeoisie would come to interpret the globalizing efforts of American businesses to escape the social welfare state established by Franklin Delano Roosevelt within the framework of the freedoms and rights of the black American civil rights movement of the 1960 s. Establishing a post-racial world of hybrids seeking equality of opportunity, recognition, and distribution to be provided by the outsourcing of jobs to ethnic others the world over would become, in other words, the intent of American capital beginning in the 1970s as they recursively reorganized and reproduced the tenets of their laws without regards to race, sex, nationality, religion, etc. on a global scale, i.e., globalization. ${ }^{63}$

American capital beginning in the 1970s sought to outsource work to other nation-states in order to escape the high cost of labor and environmental laws in the US. Given the new civil rights legislations enacted in the $1960 \mathrm{~s}$, as a result of the civil rights movement, to reinforce the American liberal bourgeois Protestant social order without regards to race, creed, nationality, etc. that discourse would be exported to other nation-states. American capital, therefore, sought to hybridized other ethnic cultures the world over via the retrenchment of the nation state and color-blind legislation in order to make social actors of other cultures known for two reasons, to socialize them to the work ethic of the globalizing process and to accumulate surplus-value as American capital sought to service the others of ethnic communities as agents of and for capital, i.e., consumers and administrative bourgeoisie controlling production for global capital, for their postindustrial economy focused on financial investment and cultural entertainment. ${ }^{64}$

In this instance of economic and cultural homogenization, globalization became, and is, both an attempt at cooptation as well as a new discursive space for counter hegemonic movements to the spirit of capitalism. The responses of "other" cultural groups within the globalizing or universalizing affects of agents of the Protestant Ethic operating out of the US determined which position was and is more accurate. If, for example, upon the encountering of the liberal bourgeois Protestant discourse of the metaphysics of the Protestant ethic and the spirit of capitalism, the response of the "other" cultural group was and or is participation in the world market system as was the case for liberal embourgeoised black Americans of the civil rights movement, culture in no way becomes counter-hegemonic. It is co-opted and becomes a subversive-less simulacra, hybrid form, of the metaphysics of globalization, i.e., a hybrid liberal bourgeois Protestant seeking economic gain, status, and social mobility within, and not against, the global capitalist social structure of inequality. In which case, the "culture of globalization" as culture group is correct. However, if the response is a return to tradition, as in the case of Islamic fundamentalism, the counter-hegemony or differentiation thesis of Huntington best represents the process over the globalization as culture position, which only highlights the cultural basis, hybrid other, for social integration of the other into the global relations of production. ${ }^{65}$

Contemporarily, only Islamic societies and the global natural environment serves as the two remaining counter-hegemonic forces to the homogenization of the world by the liberal bourgeois Protestant metaphysics of globalization (the former, Islamic societies because of its traditionalism, and the latter, the global natural environment because of the ecological and environmental crisis due to industrial pollution that threatens all life on earth). The hybridization, or liberal bourgeois Protestantism of cultural "others," which guides the behavior of many "other" cultural identities in the world-system as they seek to open up their nation-state markets for investment and participation in the global market place is a subversive-less hybrid simulacra of white liberal bourgeois Protestant ideals and actions and, contrary to the globalization as culture position, is not counterhegemonic to the globalizing process under American hegemony. ${ }^{66}$

\section{Hybridization as a Mechanism of Social Integration}

Essentially, just as in the case of communist Cuba, the Frankfurt school's "Negative Dialectics" represents the means by which the majority of liberal bourgeois black Americans, who led the integrationist movement during the 1960s, confronted their historical situation. This negative dialectic also represents the means by which hybrid elites of other cultures confront globalizing forces. The difference between the means by which contemporary Islamist and the earth are going about their fight against the liberal bourgeois Protestant "modernizing ethos" of global "national" capitalism, and 
the negative dialectics of Communist Cuba, the hybrid elites of other cultures, and the black American liberal bourgeoisie or hybrid is subtle, but the consequences are enormously obvious.

For the Frankfurt school, "to proceed dialectically means to think in contradictions, for the sake of the contradiction once experienced in the thing, and against that contradiction. A contradiction in reality, it is a contradiction against reality". ${ }^{67}$ This is the ongoing dialectic they call "Negative Dialectics:" Totality is to be opposed by convicting it of nonidentity with itself of the nonidentity it denies, according to its own concept. Negative dialectics is thus tied to the supreme categories of identitarian philosophy as its point of departure. Thus, too, it remains false according to identitarian logic: it remains the thing against which it is conceived. It must correct itself in its critical course a course affecting concepts which in negative dialectics are formally treated as if they came "first" for it, too. ${ }^{67}$

This position, as Adorno points out, is problematic in that the identitarian class convicting the totality of which it is apart remains the thing against which it is conceived. Hence communist Cuba is not an "identity-in-differential" to modernity, but a paragon of the modernizing project. As in the case of black Americans, their "negative dialectics," their awareness of the contradictions of the heteronymous racial capitalist order did not foster a reconstitution of that order but a request that the order rid itself of a particular contradiction and allow their participation in the order, devoid of that particular contradiction, which prevented them from identifying with the totality, i.e., that all men are created equal except the enslaved black American. The end result of this particular protest was in the reconfiguration of society (or the totality) in which those who exercised its reified consciousness, irrespective of skin-color, could partake in its order. ${ }^{68}$

In essence, the contradiction, as interpreted by blacks, was not in the "pure" identity of the heteronymous order, which is reified as reality and existence as such, but in the praxis (as though praxis and structure are distinct) of the individuals, i.e., institutional regulators or power elites, who only allowed the participation of blacks within the order of things because they were "speaking subjects" (i.e., hybrids, who recursively organized and reproduced the agential moments of the social structure) as opposed to "silent natives" (i.e., Nation of Islam, who were and are still "others"). ${ }^{69}$ And herein rests the problem with attempting to reestablish an order simply based on what appears to be the contradictory practices of a reified consciousness. For in essence the totality is not "opposed by convicting it of nonidentity with itself-of the nonidentity it denies, according to its own concept," but on the contrary, the particular is opposed by the constitutive subjects for not exercising its total identity. In the case of liberal black bourgeois America, the totality, American racial capitalist society, was opposed through a particularity, i.e., racism, which stood against their bourgeois identification with the whole. In such a case, the whole, universal, remains superior to its particularity, and it functions as such.

In order to go beyond this "mechanical" dichotomy, i.e., whole/ part, subject/object, master/slave, universal/particular, society/ individual, etc., by which society or more specifically the object formation of modernity up till this point in the human archaeological record has been constituted, so that society can be reconstituted wherein "Being" (Dasein) is nonsubjective and nonobjective, "organic" in the Habermasian sense, it is necessary, as Adorno points out, that the totality (which is not a "thing in itself") be opposed, not however, as he sees it, "by convicting it of nonidentity with itself" as in the case of black America and communist Cuba, but by identifying it as a nonidentity identity that does not have the "natural right" to dictate identity in an absurd world with no inherent meaning or purpose except for those which are constructed by social actors operating within a sacred metaphysic. This is not what happened in black America or in many "modernizing" nation-states under the leadership of postcolonial hybrids, but one can suggests, against conventional readings which view Islamic fundamentalism either as a reaction to modern secular discourse or the product of the "totalitarian despots" of nation-states in the middle east,$^{70}$ that this is what is taking place in the Islamic fundamentalist world (i.e., Iran) today, as well as the earth's responses to the hegemony of the American dominated capitalist world-system.

The liberal black American by identifying with the totality, which Adorno rightly argues is a result of the "universal rule of forms," the idea that "a consciousness that feels impotent, that has lost confidence in its ability to change the institutions and their mental images, will reverse the conflict into identification with the aggressor", ${ }^{67}$ reconciled their double consciousness, i.e., the ambivalence that arises as a result of the conflict between subjectivity and forms (objectivity), by becoming "hybrid" Americans desiring to exercise the "pure" identity of the American totality and reject the contempt to which they were and are subject. The contradiction of slavery in the face of equalitythe totality not identifying with itself was seen as a manifestation of individual practices, since subjectively they were part of the totality, and not an absurd way of life inherent in the logic of the totality. Hence, their protest was against the practices of the totality, not the totality itself, since that would mean denouncing the consciousness that made them whole. Just the same, the "embourgeoised hybrid" leaderships of nation-states today do not question the totality of modernity; they simply, if they do at all, question its particular failures, i.e., mainly, given the declining significance of race, class oppression. On the contrary, contemporary Islamic fundamentalist identitarian movements (i.e., Iran, Taliban, Al Qeida, Algeria), which during the Cold War were legitimized by the power elites of the American social structure to defeat communists and left wing forces in the Middle East ${ }^{70}$ have decentered or "convicted" the totality of American modernity, which today represents them as an "other," not for not identifying with itself, but as an adverse "sacred-profaned" cultural possibility against their own "God-ordained" possibility (alternative object formation), which they are attempting to exercise in the world. However, that the Islamists have reconceptualized the signifiers of their subjugators along a patriarchal and heterosexual sacred communalism, they, according to white American and hybrid liberal bourgeois Protestant powers, have reinstituted another "mechanical" form of domination, along the master/slave and self/ other, which seeks to subjugate and avow inequalities of opportunities as opposed to an "organic" solidarity constituted through mutually agreed upon rules of conduct which are sanctioned amongst various diverse groups as supposedly "represented" in post-1960s liberal bourgeois Protestant American institutions.

The same logic holds true for the earth itself. Mother Nature's ecological responses, i.e., global warming, soil erosion, resource depletion, etc., associated with capitalist relations of production, is not a conviction against capitalism for not identifying with its logic. On the contrary, Mother Nature stands as its own "God-ordained" alternative object formation, which antagonistically pins the limits to growth systemicity of the material resource framework, the earth, against the economic growth logic of the Protestant Ethic and the spirit of 
capitalism. So in the end, both the earth and Islamic fundamentalism are counter-hegemonic forces not because they attempt to convict, alas anti-globalization protests and hybrid identities, capitalist processes for nonidentity with itself, but because they attempt to convict capitalist processes as standing diametrically in opposition to their own sacred metaphysical systems.

\section{Conclusion}

In this work, I proposed that in globalization under American hegemony both the culture of globalization and the globalization as culture positions are purporting the same process, convergence, and that the only alternative to this thesis of convergence is Samuel P. Huntington's (1996) differential hypothesis, which purports a clash of civilization as a result of the intransigence positions of eight cultural frameworks, Sinic, Japan, Hindu, Islamic, Orthodox, Western Europe, North America, and Africa, which dominate the globe. In refutation to Huntington's thesis, however, I proposed the hypothesis that there are really only two opposing counter-hegemonic forces to the convergence towards Westernization or Americanization the earth itself and Islamic Fundamentalist movements. The earth is counter-hegemonic to globalizing processes because of the ecological devastations, i.e., global warming, soil erosion, resource depletion, etc., associated with capitalist relations of production, which antagonistically pins the material resource framework, the earth, against the economic growth of capitalist relations of production. Islamic Fundamentalism's anti-American traditionalism makes it a viable counter-hegemonic force to globalization under American hegemony. Hybridization, on the contrary, is not an alternative to the convergence thesis, but complements it because my conclusion is that the purposive-rationality of the hybrid cultures when they encounter globalizing processes under American Hegemony is for equality of opportunity, recognition, and distribution, not to overthrow or offer a counter hegemonic alternative systemicity to Western liberal bourgeois Protestant capitalism. In fact, hybridization for white American capital following the civil rights movement of the 1960s and passage of civil rights legislations would become the mechanism or modus operandi for social integration of the other in global capitalist relations of production, globalization, under American hegemony. To make this dual argument that on the hand hybridization following the civil rights movement of the 1960s and passage of civil rights legislations would become the mechanism of social integration for American capital, and therefore is not an alternative argument to the convergence theory. And, on the other hand, the earth itself and Islamic fundamentalism are the only opposing counter-hegemonic forces to the convergence towards Westernization or Americanization. I theoretically synthesized Weberian notions of social integration with Marxian systems integration to highlight the emergence of the Western social system, and to demonstrate how contemporarily hybridization is in fact a form of convergence using the case of the black American struggle for freedom.

The logic here is that the neoliberal policies of globalizing processes under American hegemony are the products of the metaphysics of the Protestant ethic and the spirit of capitalism. It is this metaphysical basis coupled with the experience of white American capital with the liberal hybrid black American's struggle for equality of opportunity, recognition, and distribution beginning in slavery and ending in the civil rights movement of the 1960s, which led to the passage of civil rights legislation that integrated blacks into the fabric of the society under the purposive-rationality of their liberal black hybrid leadership in the likes of W.E.B. Du Bois, Martin Luther King Jr., Barack Obama, etc., which would come to constitute the contemporary processes of globalization.

Following the civil rights movement of the 1960s and adoption of civil rights legislation such as the Civil Rights Act of 1964, the experience of white American capital with liberal hybrid blacks would give rise to hybridization as the mechanism of social integration for all ethnic minorities into American capitalist relations of production locally and globally. Locally, discrimination was outlawed throughout American society, which in theory became a color-blind multicultural social setting. Subsequently, the global outsourcing of industrial work by American capital beginning in the 1970s would be coupled with hybridization as the mechanism of social integration for ethnic others into global capitalist relations of production under American hegemony. That is, under the passage of civil rights legislation such as the Civil Rights Act of 1964 to integrate liberal hybrid blacks into the fabric of American society, the American nation-state reinforced its liberal bourgeois Protestantism without regards to race, creed, nationality, sex, religion, etc. With the advent of outsourcing or globalization under American hegemony beginning in the 1970s, other ethnic minorities the world-over were integrated or socialized, like the liberal hybrid black Americans, via ideological apparatuses such as education, the media, Protestant churches, etc., to work for American capital within the framework of this color-blind new world economic order.

In the processes of globalization, American capital sought and seeks to hybridize other ethnic cultures the world over via the retrenchment of the nation state and color-blind neoliberal economic legislation in order to make social actors of other cultures known for two reasons: first, to socialize them to the work ethic of the globalizing process; and second, to accumulate surplus-value as American capital sought and seeks to service the elite others of ethnic communities as agents of and for capital, i.e., consumers and administrative bourgeoisie controlling production for global capital, for their postindustrial economy. In this instance of economic and cultural homogenization beginning in the 1970s, globalization became, and is, both an attempt at cooptation as well as a new discursive space for counter hegemonic movements to the spirit of capitalism's processes of continual domination under American hegemony. The response of other cultures determined which position predominated. If the response is rejection of globalizing processes for a return to traditions, the discursive practices of the ethnic other is counter-hegemonic. However, if the response is for equality of opportunity, recognition, and distribution within globalizing processes, the ethnic other simply becomes a simulacrum of agents of the Protestant Ethic. In the end I conclude against the position of hybridization theorists that hybrid cultures and personalities socialized via ideological state apparatuses, education, and media, Protestant churches, sponsored by American capital are not counter-hegemonic to Westernization or Americanization but become hybrid simulacra of the latter seeking equality of opportunity, recognition, and distribution within the global capitalist world system under American hegemony. Conversely, I further argued that the earth and Islamic fundamentalists contemporarily are the only real opposing counter-hegemonic movements to Westernization or Americanization given the ecological crisis that threatens the former, i.e., the earth, and life on it, and the religious or metaphysical based anti-Americanism and capitalism of the latter, Islam.

\section{Acknowledgments}

None. 


\section{Conflicts of interest}

The author declares that there are no conflicts of interest.

\section{References}

1. Archer Margaret S. Structuration versus Morphogenesis. The British Journal of Sociology. 1982;33(4):455-483.

2. Kellner Douglas. Theorizing Globalization. Sociological Theory. 2002;20(3):285-305.

3. Giddens Anthony. The Constitution of Society: Outline of the Theory of Structuration. Cambridge: Polity Press; 1984. 16 p.

4. Jameson Fredric, Masao Miyoshi. The Cultures of Globalization. Durham: Duke University Press; 1988. 416 p.

5. Roediger, David R. The Wages of Whiteness: Race and the Making of the American Working Class. London, New York: Verso; 1999.

6. Althusser Louis. Lenin and Philosophy and Other Essays. JSTOR. 2001. 272 p.

7. Althusser Louis, Etienne Balibar. Reading Capital. Ben Brewster: Trans; 1970.338 p.

8. Helle Eisenstadt. Macro-Sociological Theory: Perspectives on Sociological Theory. United Kingdom: Arrowsmith JW, Ltd publishers; 1985. 258 p.

9. Balibar Etienne, Immanuel Wallerstein. Race, Nation, Class: Ambiguous Identities. London: Verso; 1988. 231 p.

10. Bell Daniel. The Social Sciences Since the Second World War. New Brunswick (USA): Transaction Books; 1985. 235 p.

11. Bhabha Homi. Cultural Diversity and Cultural Differences. In: Bil Ashcroft, editor. The Post-colonial Studies Reader. London and New York: Routledge; 1995a. 545 p.

12. Bhabha Homi. Signs Taken for Wonders. In: Bill Ashcroft, editor. The Post-colonial Studies Reader. London and New York: Routledge; 1995 b. $13 \mathrm{p}$.

13. Bhabha Homi. Remembering Fanon: Self, Psyche and the Colonial Condition. In: Patrick Williams, Laura Chrisman, editors. Colonial Discourse and Post-Colonial Theory A Reader. New York: Columbia University Press; 1994. 570 p.

14. Boswell Terry. Colonial Empires and the Capitalist World-Economy: A Time Series Analysis of Colonization, 1640-1960. American Sociological Review. 1989;54(2):180-196.

15. Brecher Jeremy, Tim Costello. Global Village or Global Pillage: Economic Reconstruction from the bottom up. Second ed. Cambridge, Mass: South End Press; 1988. 264 p.

16. Weber Max. The Protestant Ethic and the Spirit of Capitalism. New York: Charles Scribner's Sons; 1952. 292 p.

17. Brennan Teresa. The Two Forms of Consciousness. Theory Culture \& Society. 1997;14(4):89-96.

18. Chase Dunn Christopher, Peter Grimes. World-Systems Analysis. Annual Review of Sociology. 19995;21:387-417.

19. Chase Dunn Christopher, Richard Rubinson. Toward a Structural Perspective on the World-System. Politics \& Society. 1977;7(4):453-476.

20. Chase Dunn Christopher. The effects of international economic dependence on development and inequality: A cross-national study. American Sociological Review. 1975;40(6):720-738.

21. Clark Robert P. The Global Imperative: An Interpretive History of the Spread of Humankind. Boulder, Colorado: Westview Press; 1997. 193 p.

22. Cohen J. Protestantism and Capitalism: The Mechanisms of Influence.
New York: Aldine de Gruyter; 2002. 296 p.

23. Coser Lewis. The functions of social conflict. New York: The Free Press; 1956. $192 \mathrm{p}$

24. Crothers Charles. Technical Advances in General Sociological Theory: The Potential Contribution of Post-Structurationist Sociology. Perspectives. 2003;26(3):3-6.

25. Durkheim Emile. The Division of Labor in Society. New York: The Free Press; 1984. 462 p.

26. Eagleton Terry. Marx. New York: Routledge; 1999. 57 p.

27. Eagleton Terry. Ideology: An Introduction. London: Verso; 1991.242 p.

28. Engels Frederick. The Origin of the Family, Private Property, and the State. New York: Pathfinder Press; 1884.99 p.

29. Fanon Frantz. Black Skin, White Masks. New York: Grove Press; 1967. $225 \mathrm{p}$.

30. Fanon Frantz. The Wretched of the Earth. New York: Grove Press; 1963. $196 \mathrm{p}$.

31. Fraser Nancy. Justice Interruptus: Critical Reflections on the "Postsocialist" Condition. New York: Routledge; 1997. 256 p.

32. Frazier Franklin E. The Negro Family in America. Chicago: University of Chicago Press; 1939. 686 p.

33. Frazier Franklin E. Black Bourgeoisie: The Rise of a New Middle Class. New York: The Free Press; 1957. 46 p.

34. Frazier Franklin E. The Free Negro Family. New York: Arno Press and the New York Times; 1968. 75 p.

35. Gilroy Paul. The Black Atlantic: Modernity and Double Consciousness. Cambridge, Massachusetts: Harvard; 1993. 280 p.

36. Glazer Nathan, Daniel P Moynihan. Beyond the Melting Pot. Cambridge: Harvard University Press; 1963. 360 p.

37. Gramsci Antonio. The Modern Prince and Other Writings. New York: International Publishers; 1959. 192 p.

38. Habermas Jürgen. The Theory of Communicative Action: Life world and System: A Critique of Functionalist. Boston: Beacon Press; 1987. 232 p.

39. Habermas Jürgen. The Theory of Communicative Action: Reason and the Rationalization of Society. Boston: Beacon Press; 1984. 512 p.

40. Harris David R, Jeremiah Joseph Sim. Who is Multiracial? Assessing the Complexity of Lived Race. American Sociological Review. 2002;67(4):614-627.

41. Horkheimer Max, Theodor W Adorno. Dialectic of Enlightenment. New York: Continuum; $280 \mathrm{p}$.

42. Hudson Kenneth, Andrea Coukos. The Dark Side of the Protestant Ethic: A Comparative Analysis of Welfare Reform. Sociological Theory. 2005;23(1):1-24.

43. Laclau Ernesto, Chantal Mouffe. Hegemony \& Socialist Strategy: Towards a Radical Democratic Politics. London: Verso; 1985. 22 p.

44. Lukács Georg. History and Class Consciousness: Studies in Marxist Dialectics. Cambridge, Massachusetts: The MIT Press; 1971. 356 p.

45. Lukács Georg. A Defence of History and Class Consciousness: Tailism and the Dialectic. London and New York: Verso; 2000. 184 p.

46. Lyman, Stanford M. Postmodernism and a Sociology of the Absurd and Other Essays on the "Nouvelle Vague" in American Social Science. Fayetteville: The University of Arkansas Press; 1997. 586 p.

47. Lyman Stanford M, Arthur J Vidich. American Sociology: Worldly Rejections of Religion and Their Directions. London: Yale University Press; 1985.400 p. 
48. Lyman Stanford M. The Black American in Sociological Thought. New York; 1972. 220 p.

49. Mageo Jeannette Marie. Theorizing Self in Samoa: Emotions, Genders, and Sexualities. Ann Arbor: The University of Michigan Press; 1998.14 p.

50. Mansoor Moaddel. Islamic Modernism, Nationalism, and Fundamentalism: Episode and Discourse. Chicago: University of Chicago Press; 2005. 424 p.

51. Marshall Gordon. A Dictionary of Sociology. New York: Oxford University Press; 1998.

52. Marx Karl, Friedrich Engels. The Communist Manifesto. London, England: Penguin Books; 1964.

53. Marx Karl. Capital: A Critique of Political Economy. New York: International Publishers; 1992-1867.

54. Marx Karl. The German Ideology. New York: Prometheus Books; 1998 200 p.

55. Mason Patrick L. Race, Culture, and the Market. Journal of Black Studies. 1996;26(6):782-808.

56. McMichael Philip. Development and Social Change: A Global Perspective Los Angeles, California: Sage Publications; 2008. 347 p.

57. Ortner, Sherry. Theory in Anthropology Since the Sixties. Comparative Studies in Society and History. 1984;26(1):126-166.

58. Polanyi, Karl. The Great Transformation: The Political and Economic Origins of Our Time. Boston: Beacon Press; 1944.

59. Reyna, Stephen P. Theory in Anthropology in the Nineties. Cultural Dynamics. 1997;9(3):325-350.
60. Said Edward. Orientalism. New York: Vintage Books; 1979.

61. Sennett Richard. The Corrosion of Character. New York: WW Norton \& Company; 1998.

62. Sklair Leslie. Sociology of the Global System. Baltimore: Westview Press; 1995.

63. Slemon Stephen. The Scramble for Post-colonialism. In: Bill Ashcroft, editor. The Post-colonial Studies Reader. London, New York: Routledge; 1995:45-52.

64. Wallerstein Immanuel. The Rise and Future Demise of the World Capitalist System: Concepts for Comparative Analysis. In: Hamza Alavi, Teodor Shanin, editors. Introduction to the Sociology of "Developing Societies". New York: Monthly Review Press; 1982:29-53.

65. Wilson Kirt H. Towards a Discursive Theory of Racial Identity: The Souls of Black Folk as a Response to Nineteenth-Century Biological Determinism. Western Journal of Communication . 1999;63(2):193-215.

66. Wilson William J. The Declining Significance of Race: Blacks and Changing American Institutions. Chicago and London: The University of Chicago Press; 1978. 272 p.

67. Adorno, Theodor W. Negative Dialectics. New York: Continuum. 2000. $440 \mathrm{p}$.

68. Wilson William J. The Truly Disadvantaged. Chicago and London: University of Chicago Press; 1987. 320 p.

69. Winant Howard. The World is a Ghetto: Race and Democracy since World War II. New York: Basic Books; 2011. 448 p.

70. Wright Kai. The African-American Archive: The History of the Black Experience in Documents. New York: Black Dog \& Leventhal Publishers; 2001. $736 \mathrm{p}$. 